\title{
John Wesley and Methodist Responses to Slavery in America
}

\section{Daniel J Pratt Morris-Chapman}

The Revd Dr Daniel Pratt Morris-Chapman is a British Methodist presbyter serving as a Methodist Mission Partner in a migrant congregation in Novara, Italy. He is also a Research Fellow at Wesley House Cambridge.

dp604@cam.ac.uk

Novara, Italy

John Wesley considered the slave trade to be a national disgrace. However, while the American Methodist Church had initially made bold declarations concerning the evils of slavery, the practical application of this principled opposition was seriously compromised, obstructed by the leviathan of the plantation economy prominent in this period of American history. This paper surveys a variety of Methodist responses to slavery and race, exploring the dialectical germination of ideas like holiness, liberty and equality within the realities of the Antebellum context.

WESLEY • SLAVERY • RACE • ANTEBELLUM • AMERICA 


\section{Introduction}

In Wesley's time a form of hyper-Calvinism had been mis-used to justify the class system and maintain socio-economic inequality. Thus, one's place in the world, and the problems within society at large, were often accepted passively as being part of the sovereign will of God'. Wesley's message that 'all ... may be saved,' his rejection of theological forms of fatalism, and his embrace of the egalitarianism implicit within Arminianism, injected hope and industry into the Methodist people, encouraging them to take responsibility for their fate. No longer seeing themselves as reprobates, helpless victims of a divinely inspired plot to keep them poor, they were empowered with a confidence to address their own circumstances and, moreover, to engage in wider social reform. ${ }^{2}$

To a large extent, the principles of equality and social holiness, ${ }^{3}$ manifest in Wesley's theology and ministry, animated Methodist responses to slavery and racial inequality. ${ }^{4}$ Instead of accepting societal evils as a part of the sovereign will of God, or an inevitable consequence of the fall, many began to realise their potential agency for change and recognised the need to challenge social problems like slavery. ${ }^{5}$ However, within the American context, Wesley's idea of a social religion would have to compete with the notion that Church and State should be kept apart. ${ }^{6}$ This entrenched political tradition, combined with the racist conception of slavery endemic at this time, complicated the digestion of Wesley's theological principles within the American psyche.

This article will explore the interplay between these different ideas as we survey Wesley's and American Methodist responses to slavery. While the article will deal extensively with the reality of slavery and racism in the United States during the Antebellum period (before the American Civil War), it is important to discuss John and Charles' perspective on these issues. This is necessary because it helps illustrate the extent to which American Methodism departed from the views held by the Wesleys and facilitates a discussion of some of the reasons for this divergence.

\section{Wesley's Response to Slavery and Race}

During their time in America the Wesleys were first-hand witnesses of the evils of slavery. In his journal Charles Wesley recounts the barbaric treatment slave owners 'daily practise upon their fellow-creatures' including whipping, hammering nails through their ears, drawing their teeth, pouring hot wax and 
scalding water upon their flesh, and even 'giving a [White] child a slave of its own age to tyrannise'. While surrounded ${ }^{8}$ by these 'shocking instances of diabolical cruelty' the Wesleys practised kindness towards the African Americans they encountered and John preached to slaves whenever he had opportunity, even on the boat back to England. ${ }^{9}$

On his return to Britain, John continued to support evangelistic work among slaves in Virginia ${ }^{10}$ and repeatedly declared his belief that God's 'saving health' should 'be made known to all'.11 In his journal he even states that an African Christian woman in one of his societies is 'fuller' with the 'pure love of God'than any other (White) Christian in her area. ${ }^{12}$ In his Notes on the New Testament he called slave traders 'man stealers', believing it to be the worst of crimes. ${ }^{13} \mathrm{He}$ considered England's participation in the slave trade to be a national disgrace. ${ }^{14}$

\section{Wesley and Racism}

Wesley believed slavery (in all its forms) to be irreconcilable with any 'degree of either justice or mercy'. ${ }^{\prime 5}$ However, although Wesley's opposition to slavery and his treatment of African people were exemplary, it is perhaps unsurprising that his writings occasionally betray some of the ethnocentric assumptions of this period. ${ }^{16}$ Hence, while Wesley does not appear to view Europeans as superior, his journals often record his being amazed by both the virtue of Africans and by their aptitude for instruction. ${ }^{17}$ Moreover, in his Essay on Original Sin (1757) Wesley uses the racial term 'Hottentot' to illustrate what he considers to be the barbarity of humankind without God; the implication being that Wesley views the culture of this Southern African people as being somehow inferior to that of European nations. ${ }^{18}$ Nevertheless, in his Thoughts upon Slavery (1774) he acknowledges that the African societies, from which the slaves are taken, have developed political and judicial systems. ${ }^{19}$ He concludes that, if such accounts are true, they are superior in virtue than slave-trading nations like 'England and France' and that those who seek 'genuine honesty' ought to go to 'Benin, Congo, or Angola'. ${ }^{20}$ Moreover, there are points in his writings where Wesley challenges stereotypes about Black people ${ }^{21}$ and suggests that the only reason 'why one part of mankind have Black skins, and the other White' is 'climate'.. He thus appears to reject the idea, common in his day, that White people are superior for he emphasises that, whether White or Black, we all 'have the same flesh and blood.22

\section{Slavery and American Independence}

The theme of slavery arises most often in Wesley's controversy with the 
advocates for the independence of America from Britain. The colonies had been paying taxes without obtaining political representation. Thus, some advocates of independence argued that 'all Americans are slaves' because they have no voice in the British parliament. ${ }^{23}$ In response to this argument Wesley pointed out that:

Slavery is a state wherein neither a man's goods, nor liberty, nor life, are at his own disposal. Such is the state of a thousand, of ten thousand, Negroes in the American colonies. And are their masters in the same state with them? in just the same slavery with the Negroes? Have they no more disposal of their own goods, or liberty, or lives? Does any one beat or imprison them at pleasure; or take away their wives, or children, or lives; or sell them like cows or horses? This is slavery; and will you face us down that the Americans are in such slavery as this? ${ }^{24}$

While Wesley was correct to criticise this hypocrisy, his opposition to American independence was highly misjudged if not outright foolish. ${ }^{25}$ Wesley had sent a number of preachers to America (1769) who had upheld his views upon slavery. ${ }^{26}$ However, his opposition to American calls for independence resulted in them being viewed as puppets of the British government. ${ }^{27}$

In a series of tracts and essays Wesley allowed his arguments against slavery to become intertwined with his critique of Republicanism, which he described as the most 'despotic' form of government 'under heaven'. ${ }^{28}$ It would be anachronistic to judge Wesley's political views here. ${ }^{29}$ Nevertheless, in the words of Francis Asbury, Wesley's opposition to American independence made him the most 'obnoxious' man 'in the [new] world' and cast a colonial shadow over the American Methodist movement. ${ }^{30}$ As a result, many of Wesley's preachers were recalled home - diluting the strength of his anti-slavery perspective within this Church's hierarchy. ${ }^{31}$ In time, this would render the newly formed Church unable to meet the leviathan of institutional slavery. ${ }^{32}$ Had these ministers stayed, maybe the story would have been different. ${ }^{33}$

\section{Methodist Responses to Slavery in America}

When America finally gained its independence from Britain, Wesley recognised the separation of American Methodism and consecrated Thomas Coke (17471814) as its superintendent. However, the Americans wanted Asbury (who had 
remained during the war) as their bishop and the Methodist Episcopal Church (MEC) was formally created (1784). ${ }^{34}$ Initially Wesley's position on slavery was reflected in the discipline of the American Methodist conference. ${ }^{35}$ However, while Asbury and Coke expected preachers to emancipate their slaves, ${ }^{36}$ the fierce opposition they encountered, particularly in the south, led them to modify the Church's position. ${ }^{37}$ In little over a decade, ${ }^{38}$ the persecution of Methodist preachers and the refusal of slave owners to allow access to their slaves led the church to soften its approach. ${ }^{39}$ By the turn of the eighteenth century instructions concerning emancipation were diluted further, with the clause' if it be practicable' being added to the direction to free slaves. ${ }^{40}$ In 1808 , all references to slaveholding in relation to private members were removed, and by 1812 each annual conference was allowed 'to form their own regulations relative to buying and selling' slaves. ${ }^{41}$ Finally in 1824 the church, instead of publicly forbidding the ownership of slaves, encouraged slave owners to provide Christian education for them. ${ }^{42}$

Having illustrated how quickly Wesley's opposition to slavery became diluted within American Methodism it is necessary to survey some of the different responses to slavery by the newly formed Methodist Episcopal Church during the Antebellum period. Essentially, at least three responses to slavery can be identified within this period: (1) Racist pro-slavery response, (2) Racist antislavery response and (3) Immediate Abolition.

\section{(1) Racist pro-slavery response}

The degree to which leaders like Asbury, who were opposed to slavery, could influence Methodists to release their slaves was seriously impeded by the lucrative nature of the plantation economy and the doctrine of the separation of church and state. ${ }^{43}$ For example William Capers (1790-1855), a prominent clergyman in the South, considered that 'the question of the abolition of slavery' was not a religious but a civil question. Capers had no objections to what he considered to be humane forms of slavery and, like many, considered slavery biblical. Incredibly Capers, like a number of Methodists in the South, considered that slavery actually 'tended to the salvation of the Negroes'.44 In this vein, in 1824, the South Carolina Conference created a special department that would be focused upon the spiritual wellbeing of slaves. ${ }^{45}$ Similar missions also took place in Georgia. ${ }^{46}$ However, because plantation owners feared that spreading the gospel among the slaves would lead to insurrections, such missions to the slaves soon ran into difficulties. ${ }^{47}$ Nevertheless, an Address delivered in Charleston before the Agricultural Society of South Carolina provided 
Capers, who firmly believed in evangelising slaves, with powerful arguments that would enable him to convince plantation owners that evangelising slaves could work in their favour. ${ }^{48}$ In this address, the Right Honourable Charles Cotesworth Pinckney (a plantation owner) argued that 'nothing is better calculated to render man satisfied with his destiny in this world' than religion. ${ }^{49}$ Using these ideas, Capers appealed to slave owners with the same argument and maintained that Christianity, with its offer of eternal life, could substitute the slaves' dreams of emancipation in this world. Moreover, he argued that Christianity, instead of encouraging insurrections, could make slaves more obedient to their masters. ${ }^{50}$ To this effect, Capers redacted the gospel in order to create a catechism that would imprint upon the slaves that, if they were dutiful and obedient workers in this life, God (the supreme master) would reward them with eternal life. In order to receive this reward it was essential for them to perform their duties wholeheartedly and maintain good relationships with their earthly masters. ${ }^{51}$ The nature of this gospel is captured in the autobiography of former slave and abolitionist Henry Bibb (1815-1854).

They say, 'Servants be obedient to your masters; - and he that knoweth his masters will and doeth it not, shall be beaten with many stripes - means that God will send them to hell, if they disobey their masters. $^{52}$

In offering this form of Christianity to the slaves, Capers was offering the plantation owners a more effective workforce. ${ }^{53}$ It was this that convinced the slave holders to accept such missions. By offering a perverted gospel of obedience to God and faithfulness to the interests of one's earthly master, Capers packaged the mission as something that would reinforce, rather than undo, the institution of slavery. ${ }^{54}$

The results of the spreading of this gospel, which encouraged slaves to remain servile, were very much appreciated by plantation owners across the South. In 1837, the South Carolina Conference reported how slaves were now 'pointed from earliest infancy to a Master in heaven, whose eye sees in darkness as in light ${ }^{\prime 55}$. Thus, because slaves responded in the way intended by overseers like Capers it was reported that slaves were now less likely to rebel and that they were more honest workers than they had been previously. Tragically, the notion that in the next life their situation would be better quenched their thirst for emancipation in the present. The missions applauded themselves for this and for having 'humanised'slavery, improving the conditions in which these people 
were kept and, moreover, for having provided slaves with a sense of purpose. Southern Missionaries claimed that their efforts had made American slaves more superior to any Africans, whether they be in the North or in Africa. Moreover, they believed Northern abolitionists, by offending the plantation owners, were jeopardising the growth of the Church among the slaves. In sum, these missions tried to humanise the institution of slavery. Rather than rejecting it they wanted to perfect it. ${ }^{56}$

It is difficult to see how Wesley's name could ever have become attached to Methodists like Capers. We can scarce imagine what John Wesley might have said to him if the two had met. Undoubtedly there is a vast chasm between the empowering transforming theology of John Wesley and the willful misrepresentation of Caper's false gospel of white supremacy. Unfortunately, while Wesley was right about slavery, he was wrong about American independence and his opposition to it hampered the transmission of Wesley's views on this matter in the United States. As Methodism spread into the South, official church legislation against slavery was viewed as an expression of a 'British Conscience' imposed by a'British leadership'.57

\section{(2) Racist anti-slavery response}

In the North the situation was even more puzzling; a peculiar combination of both anti-slavery sentiments and White supremacy. Though many Northern states had legislated against slavery, their conception of liberty and equality did not entail racial equality. ${ }^{58}$ The mentality of people at this time is captured in the writing of Thomas Jefferson (1743-1826) - third President of the United States (1801-1809) and principal author of the declaration of Independence who considered Africans to be inferior to Europeans. ${ }^{59}$ In his published work he states that, differences of 'colour' and 'faculty' are a 'powerful obstacle to the emancipation of [Black] people..$^{60}$ Thus, while he wished to affirm 'the liberty of human nature' he was also 'anxious to preserve its dignity and beauty'. He believed Whites were 'of superior beauty' to Blacks and warned that the 'slave, when made free, might mix [sexually]' with Whites, 'staining the blood of his master'. Jefferson considered that, once freed, slaves should 'be removed beyond the reach of mixture' and proposed that freed slaves be relocated elsewhere. ${ }^{61}$

\section{Colonisation}

Jefferson supported the Society for Colonizing the Free People of Colour in Africa (1816), an organisation created to return free slaves back to Africa (Liberia). At 
their first meeting they summarised their position concerning the problem of integrating free Blacks in a White dominated racist society as follows.

We say, in the declaration of independence, 'that all men are created equal' ... Yet it is considered impossible ... with the present feelings towards [Black] people, that they can ever be placed upon this equality, or admitted to the enjoyment of these 'inalienable rights,' whilst they remain mixed with [Whites]. Some persons may declaim, and call it prejudice. No matter-prejudice is as powerful a motive, and will as certainly exclude them as the soundest reason. ${ }^{62}$

The profound aversion that many Whites had to the presence of free Blacks in society, fearing that it could lead to interracial marriage and the right to vote, led many (including Methodists) to conclude that the best thing to do was to send the free slaves back to Africa. ${ }^{63}$ Ironically, those slaves who were willing to go to Liberia needed a pastor and thus, paradoxically, the colonization movement led to the ordination of African American Methodists such as David Payne to provide pastoral care and to facilitate the evangelisation of Africans. ${ }^{64}$

\section{Segregation in the Church}

White American Methodists were extremely supportive of the colonization movement. Here the degree to which racism was entrenched within American culture, even within states where slavery was illegal, should not be underestimated. ${ }^{65}$ In practice, the American Methodist Episcopal Church (MEC) engaged in racial segregation from its beginnings. ${ }^{66}$ From 1787 to 1829 , Methodist preachers attempted to integrate Africans into the Church. However, while Black members were permitted to engage in lower levels of church leadership, ecclesiastical power remained concentrated in White hands. ${ }^{67}$ As early as 1780 , immediately following a bold declaration against slavery, the conference promoted the idea of White supremacy: stating that the meetings of 'coloured people' must be supervised by 'White persons'.68 Thus, while the Conference had declared its opposition to slavery, ordinary Methodists had 'difficulty in welcoming Blacks fully into the household of faith and left them to listen through the window. Or... sent [them] to the barn'.69 The strange way in which the Church's antislavery stance was 'laced' with racism is manifest in the writings of Freeborn Garrettson. Upon his conversion he immediately freed all of his slaves. ${ }^{70}$ However, while Garrettson was an ardent evangelist, who suffered for his opposition to slavery, he still supported the idea of racial 
segregation and suggested Africans were inferior to Europeans. ${ }^{71}$ Garrettson was not alone in holding these prejudices.

\title{
African Preachers
}

Earlier it was noted that Wesley, who generally seems to have affirmed the equality of Africans and Europeans, occasionally betrayed his surprise when encountering intelligent and virtuous Black people. At one point in his journal (June 1780) Wesley's retelling of a racist joke might be interpreted, at an unconscious level, as a collusion with the idea of White supremacy.

\begin{abstract}
On Sunday, 11, preached at Kirton about eight, to a very large and very serious congregation 5 only before me stood one, something like a gentleman, with his hat on, even at prayer. I could scarce help telling him a story: In Jamaica, a negro passing by the Governor pulled off his hat; so did the Governor; at which one expressing his surprise, he said, 'Sir, I should be ashamed if a negro had more good manners than the Governor of Jamaica." ${ }^{72}$
\end{abstract}

The same dynamic, though often implicit, is found in the preachers he sent to America, who were astounded by the preaching abilities of (Black) Harry Hosier (1750-1806), who they considered to be 'one of the best preachers in the world' ${ }^{73}$ Despite his great ability, Hosier was never ordained and although he regularly accompanied Asbury, Coke and Garrettson on their preaching tours, he was lodged in segregated accommodation. ${ }^{74}$ Moreover, although it is suggested that he was essential to the growth of Methodism - a Billy Graham of his time - 'Black Harry' was regarded as an anomaly, an 'African wonder.'75 Many Methodists refused to accept that an African could be so gifted and assumed he was a White man in disguise. ${ }^{76}$

Richard Allen (1760-1831), founding Bishop of the African Methodist Episcopal Church (AMEC), represents a similar case. Like Hosier he was well connected with figures like Asbury and Garrettson. ${ }^{77}$ Nevertheless, although his preaching encouraged many Africans to become Methodists, ${ }^{78}$ his attempts to nurture these converts within the existing church structures proved impossible. ${ }^{79} \mathrm{He}$ recounts how, one particular Sunday, as they were praying they were forcefully removed from their seats.

We felt ourselves much cramped [and] were considered as a nuisance... [We] usually attended St. George's Church in Fourth 
street; [but] when the coloured people began to get numerous in attending the church, they moved us from the seats we usually sat on, and placed us around the wall.... we bore much persecution from many of the Methodist connexion. ${ }^{80}$

It is not at all surprising that this 'racial discrimination led to separate houses of worship for congregants of African descent. ${ }^{81}$ According to Hempton, 'the layers of paternalism, social segregation, and liturgical discrimination ... proved impossible to bear for many African Americans.' While they had initially believed that they belonged to a 'movement of spiritual and social egalitarianism' they soon discovered that myriad restrictions dictated 'the kinds of role they could perform in predominantly White congregations'.82 Although African Americans were gradually permitted to participate in lower levels of church leadership becoming class leaders, exhorters and preachers - few were ordained deacons and none were ordained as elders. ${ }^{83}$ Thus while individual Black congregations had a degree of autonomy, their affairs ultimately remained in the hands of a White leadership, both ministers and lay leaders, who monitored the activities of the Black members. ${ }^{84}$ For this reason, the pull towards separation became inevitable as 'interracial fellowship around the dinner table did not become interracial fellowship around the conference table' ${ }^{85}$ All this serves to illustrate that although Northern states opposed slavery, the majority of Whites believed Blacks to be inferior and maintained restrictive laws designed to segregate Blacks so as to prevent them from taking leadership positions and integrating fully into society. ${ }^{86}$

\section{Black Methodist Denominationalism}

Under these racist conditions it was perhaps inevitable that a Black and Methodist denominationalism would arise out of Wesley's theological principles. First Peter Spencer founded the African Union Church in Wilmington, Delaware in 1814. In Philadelphia, 1816, Richard Allen's Bethel Church seceded along with Daniel Coker's Baltimore congregation to form the African Methodist Episcopal Church. In 1822 in New York, the African Methodist Episcopal Zion Church was formed. ${ }^{87}$ While it is clear that these Christians would no longer tolerate the institutional racism they had experienced, their continued use of the name 'Methodist' indicates a strong affinity with their Wesleyan heritage. It is possible that the ongoing appeal of Methodism to slaves and free Blacks was that it connected Christianity to physical and spiritual deliverance. ${ }^{88}$ Methodist hymns in particular, with their metaphors of imprisonment and freedom, resonated with the African American community 
and these hymns were cited by prominent African American Methodists. ${ }^{89}$ Moreover, the emphasis on personal transformation and social responsibility within Methodist teaching encouraged former slaves to view themselves as agents capable of participating in the transformation of society. ${ }^{90}$

\section{(3) Immediate Abolition}

The vanguard of Abolition (immediate emancipation) came not from the White community but from African Americans, including Methodists who connected their freedom in Christ, about which they sang in Charles Wesley's hymns, to liberty on earth and who, moreover, believed themselves capable of realising it. ${ }^{91}$ A good example of this is the former slave and abolitionist David Walker (1796-1830) who was inspired by the Wesleys, and particularly by Charles' hymns, to denounce White supremacy. ${ }^{92}$ Like many African Americans Walker found John and Charles Wesley's emphasis on personal transformation and social responsibility empowering and through his publication, Appeal to Coloured Citizens of the World (1829), Walker became a key agent in calling for the transformation of society. ${ }^{93}$ His Appeal criticised both racist pro-slavery Christianity and racist anti-slavery Christianity. ${ }^{94} \mathrm{His}$ work was a call to arms, to 'awaken ... my afflicted, degraded and slumbering brethren', and to galvanise abolitionists into action. ${ }^{95}$ Like many African Americans Walker viewed colonisation as racism ${ }^{96}$ and called for immediate freedom (as opposed to the gradualism supported by many within the Methodist church). ${ }^{97}$ Copies of his book were smuggled into ports across the South, striking fear into slave owners who put a large bounty upon his head. Walker was found dead two years later in suspicious circumstances. ${ }^{98}$ Nevertheless, his martyrdom motivated a number of important Black and White Abolitionists into action. ${ }^{99}$

\section{Underground Railway}

Hezekiel Grice (c.1801-1873), upon whom Walker's Appeal had a profound impact, was a freed slave who settled in the North. Weary of the discrimination faced by his brothers and sisters he called for a National Negro Convention to discuss the merits of whole scale emigration to Canada where they could truly be free. ${ }^{100}$ As a result the American Society of Free People of Colour was founded (1830) and had its first meeting in the Bethel African Methodist Episcopal Church in Philadelphia. The aim of this organisation was to promote emigration to Canada for African Americans. ${ }^{101}$ Following the American Revolution, Africans who had sided with the British had been relocated to Nova Scotia. By the turn of the century slavery had already begun to decline in Canada and by 1833 it was 
completely abolished. As a result it became a true safe haven for slaves who found their way there using the stars to guide them north. ${ }^{102}$ Laws such as the Fugitive Slave Act (1850), which gave slave holders the right to recapture escaped slaves in any part of the country, forced even more African Americans to emigrate to Canada and a coordinated humanitarian effort known as the underground railway developed to facilitate the passage of slaves to their freedom. ${ }^{103}$

A leading Methodist figure in the underground railway was Josiah Henson (1789-1883) who, after escaping to Canada, became an elder in the AME church. He regularly challenged his congregations to help free their brothers and sisters who remained in captivity. ${ }^{104}$ Harriet Tubman (1822-1913), a member of the AME Zion church, also played a pivotal role in the underground railway. Like Henson, she had escaped from slavery with little information of where to go but had, providentially, encountered a series of White families who abetted her escape. Once she reached safety, she returned every year to rescue other slaves. While Tubman and Henson had escaped with the barest of information and with meagre support, future escapees would inherit the knowledge that they, and others, had acquired of the various safe houses along the way. ${ }^{105}$

Frederick Douglass, a friend of Tubman who had also been a slave in Maryland, was also a member of the AME Zion church. ${ }^{106}$ Douglass founded the North Star abolitionist newspaper (1847-) and publicly backed the work of the Underground Railroad. ${ }^{107}$ Douglass' keen mind and penetrating critiques of slavery led him to become a national leader in the abolitionist movement as well as a powerful advocate for Women's rights. ${ }^{108}$ Sojourner Truth (1797-1883), also fought for the equality of men and women. A former slave, she became a member of the AME Zion church on her release and, against the odds, became an itinerant lecturer. Though she was unable to read, she travelled 'up and down the land, convicting people of the "sin" of slavery and calling for its immediate abolition at every opportunity'.109

\section{Schism}

At around this time, Orange Scott (1800-1847), a Methodist Episcopal presiding elder, became convinced of the anti-slavery cause. Inspired by John Wesley, and convinced that the American Methodist tradition had abandoned his values, he wrote:

Spirit of Wesley, where hast thou fled? Who now, in the M. E. Church, except the persecuted abolitionists, cry out for 'instant' emancipation? 
Who now puts 'all slave holders, of whatever rank and degree,' 'EXACTLY ON A LEVEL WITH MEN STEALERS' Who makes slave holders 'partakers with a thief?' Who now charges them with 'blood guiltiness?' ('Thy hands, thy bed, thy furniture, thy house, thy lands, are at present stained with blood I') Certainly not Bishop H., not President F. No, not even the abolitionists. We believe with Mr. Wesley; but alas! we have spoken in whisper tones and in soft language compared with his. ${ }^{110}$

Here Scott identifies the case for immediate abolition with John Wesley, even suggesting that Wesley was stronger in his criticism of slavery than Scott's contemporary abolitionists. Scott's writing is saturated with citations from Wesley's Thoughts upon Slavery and repeatedly compares Wesley's views with the decisions and language of the General Conferences of Georgia and Baltimore. In doing so Scott used Wesley's writing to hold the American Methodist Episcopal Church to account by demonstrating the profound divergence between John Wesley's position and the way in which the American Methodist tradition had developed.

Scott was a powerful critic of slavery and, using Wesley's writings, wrote a series of articles on the subject of immediate abolition in the Conference Newspaper (1835) and gave a powerful public statement against slavery in an address at the General Conference of 1836. ${ }^{111}$ Nevertheless, as the idea of immediate abolition began to influence more and more Methodists, the General Conference refused to change its official position of gradual emancipation developed in order to appease Methodists in states where slave holding was legal. ${ }^{12}$ In 1836, in response to calls for the instantaneous abolition of slavery, the 'delegates of the annual conference' in Cincinnati stated themselves to be 'decidedly opposed to modern Abolitionism, and wholly disclaim any right, wish, or intention to interfere in the civil and political relation between master and slave as it exists in the slave states of the union.' ${ }^{13}$ The same argument was made again four years later in 1840 at the conference in Baltimore where Charles Elliot stated that 'No Church can assume the power of making laws', for the 'Church cannot interfere with the political relations of her members', 114 Scott rejected this artificial distinction between politics and religion ${ }^{115}$ and in response to these arguments declared that it is 'always right' for the Church to 'oppose all sin'. ${ }^{116}$ He maintained that 'immediate emancipation', is the 'duty of the master, and the right of the slave' and that 'holding the human species as property, is a most flagrant sin, and that no circumstances', political or not, 'can 
make it otherwise.'117 However, he was unable to affect the official position of the MEC and Scott left the church. His departure, though, only served to increase calls for the immediate abolition of slavery. By 1844 the Methodist Church split into Northern and Southern branches - the former supporting the abolition of slavery and the latter continuing to support slavery.

\section{Conclusion}

In surveying pro- and anti-slavery responses, it is clear that American Methodists struggled to uphold Wesley's position on this matter. While an antislavery position was initially published in the Methodist Episcopal Church's discipline, Wesley's theological principles proved difficult to apply in practice as his successors struggled to surmount the concrete reality of slavery within a totally different socio-political context, and the position was modified, even abandoned. Although the institutional church regularly compromised the integrity of Wesley's social vision of Christianity, the idea that Methodism could only flourish by engaging in struggles against societal evils like slavery was regurgitated by African Methodists and others, who recognised themselves as agents of God's transforming power in this world. Wesley observed that the 'beauty of holiness' is that it 'cannot' be hidden; ${ }^{118}$ and this persisting Wesleyan conviction is inherited by Methodist engagement with the continuing issues of racism and slavery today. ${ }^{119}$

\section{Notes}

1. At this time the concept of predestination and election were exploited in such a way as to convince members of the lower strata of English society that their position was pre-ordained by God. Wesley's declaration that 'all ... may be saved,' Brendlinger, p. 160.

2. Wesley 1782, p. 16; Brendlinger, p. 161.

3. While I concur with Thompson's thesis that Wesley's conception of holiness should not be confused with the giustizia sociale of the Jesuit political commentator Luigi Taparelli d'Azeglio I believe it is pertinent here to explore the way in which Wesley's understanding of the public manifestation of a holy life challenged the notion that religion and politics should be separate. For further discussion see: Thompson, p. 153.

4. Wesley maintains that to ignore the 'sorrow' and 'miseries' of others, and yet claim that one's 'earnest desire' is for 'universal holiness' is absurd. Wesley 1872, vol. 5 , pp. 308-309.

5. Brendlinger, pp. 160-161. 
6. Wesley believed it to be 'impossible' for a real Methodist to keep their Christianity private. He rejected the idea that holiness flourishes in separation from the world. Wesley 1872, vol. 5, pp. 294-295, 302.

7. Jackson vol.1, pp. 71-72.

8. While Georgia officially forbade slavery at this time one did not have to go far to witness these atrocities.

9. Wesley 1872, vol. 1, pp. 40, 49, 70, 72 .

10. Wesley 1872, vol. 2, pp. 337-338, 354-355, 392.

11. Wesley 1872 , vol. 2 , pp. 433,464

12. Wesley 1872 , vol.4, p. 180.

13. He writes: 'Man stealers-The worst of all thieves, in comparison of whom highwaymen and house breakers are innocent! What then are most traders in negroes, procurers of servants for America, and all who list soldiers by lies, tricks, or enticements.'Wesley 1853, p. 539.

14. Wesley 1872 , vol.11, p. 145.

15. Wesley 1872, vol.11, pp. 70-72.

16. Wesley's position was contrary to Whitefield who owned slaves and even petitioned for the State of Georgia to legalise it. Brendlinger, p. 57.

17. For further discussion see: Wesley 1872, vol. 4, p. 184; Brendlinger, pp. 64-71.

18. Wesley 1872, vol.9, pp. 209-210.

19. Wesley 1872 , vol.11, p. 62.

20. Wesley 1872, vol.11, p. 65.

21. Wesley 1872 , vol.4, pp. 15-16.

22. Wesley 1872 , vol.13, p. 497.

23. Wesley 1872, vol.11, p. 117. For example, Richard Price went as far as to argue that: 'A country that is subject to the legislature of another country, in which it has no voice, and over which it has no control, is in slavery. The [United] kingdom has power to make statutes to bind the colonies in all cases whatever! Dreadful power indeed! I defy any one to express slavery in stronger terms.' Price, pp. 19-20.

24. Wesley 1872, vol.11, p. 109.

25. Wesley's fears were rooted in the fact that during the 1770s he had become increasingly aware of the revolutionary spirit spreading across Europe and culminating in France, 1789. For further discussion see: Clark, J, pp. 236-240.

26. These included Richard Boardman, Joseph Pilmore, Thomas Rankin, George Shadford and others.

27. Melton, pp.110-111.

28. Wesley 1872, vol.11, p.87. For further discussion see: Raymond, pp.316-328.

29. Equally embarrassing is Wesley's suggestion that press freedom should be curbed in order to stop the circulation of these ideas. Wesley 1872, vol.11, p.43-44.

30. Clark, E., vol.3, p.62; Lawrence, p.157.

31. Lee, J., pp. 54-60.

32. Matthews 1965, pp. 56-57.

33. Wesley's unswerving obedience to the British crown is unsurprising. During this time these ideas were taught to all students at Oxford University. Wesley himself 
states that he was 'bred' from 'childhood in the highest notions of passive obedience and non-resistance.'Telford, vol.6, p. 156; Gibson, pp. 29, 35-36.

34. Melton, pp. 44-45.

35. 'Quest. 17. Does this Conference acknowledge that slavery is contrary to the laws of God, man, and nature, and hurtful to society; contrary to the dictates of conscience and pure religion, and doing that which we would not others should do to us and ours? Do we pass our disapprobation on all our friends who keep slaves, and advise their freedom? Answ. Yes.' Unknown 1840, p. 12.

36. Initially Asbury considered that 'if the Methodists [did] not ... emancipate their slaves, God [would] depart from them.'Baker, pp. 121-122.

37. Melton, p. 31; Coke writes that: 'We thought it prudent to suspend the minute concerning slavery, on account of the great opposition that had been given it, our work being in too infantile a state to push things to extremity.'Person, p. 195.

38. In 1796 individual conferences were authorised to 'make whatever regulations they judge proper' regarding slavery. Unknown 1798, p. 170.

39. Brendlinger, p. 58; Matthews 1963, p. 615.

40. A report to the 1804 general conference states that 'When any travelling preacher becomes the owner of a slave, or slaves, by any means, he shall forfeit his ministerial character in our Church, unless he execute, if it be practicable, a legal emancipation of such slaves, conformably to the laws of the state in which he lives.' Unknown 1804, p. 215.

41. Emory, p. 331.

42. 'All our preachers shall prudently enforce upon our members the necessity of teaching their slaves to read the word of God; and to allow them time to attend upon the public worship of God.' Emory, p. 332. For further discussion on this shameful transition see: Matlack, p. 36; Matthews 1965, p. 24.

43. Matthews 1963, p. 627.

44. Matthews 1963, p. 621.

45. Matthews 1963, p. 617.

46. Wightman, pp. 290-293.

47. Matthews 1965, p. 71.

48. Pinckney, pp. 4-5, 10-14, 16-18.

49. Matthews 1965, p. 71.

50. Matthews 1965, p. 72.

51. Matthews 1965, pp. 77-78.

52. Bibb, p. 23.

53. Coke also engaged in preaching this deplorable gospel:'I bore a public testimony against slavery, and have found out a method of delivering it without much offence, or at least without causing a tumult: and that is, by first addressing the negroes in a very pathetic manner on the duty of servants to masters; and then the Whites will receive quietly what I have to say to them.' Person, p. 185.

54. Matthews 1965, pp. 77-78. The powerful effect of this gospel, of obedience to ones master, can be seen in Josiah Henson's, abolitionist and minister (17891883), autobiography, in which he narrates how he resisted the chance to free both himself and his master's slaves (who he had been charged to transport to 
Kentucky), because of a promise he had made to his master. The Abolitionist Frederick Douglas (c.1818-1895) also gives us an insight into the psychological effects of this counterfeit gospel. For further discussion see: Henson, pp. 23-24; Douglass 1849, p. 103.

55. Matthews 1965, pp. 79-80.

56. Matthews 1965, pp. 83-85.

57. Richey, p. 58.

58. Thus, even as slavery became illegal in many Northern states, people still believed Blacks to be inferior and maintained restrictive laws designed to segregate Blacks and keep them from integrating into society by preventing them from taking certain jobs and restricting their right to vote. Matthews 1965, pp. 62-63; Melton, pp. 102, 240; Holm, p. 34.

59. He writes: 'Never yet could I find that a Black had uttered a thought above the level of plain narration; never see even an elementary trait of painting or sculpture.' Jefferson, p. 148.

60. Jefferson, p. 154.

61. Jefferson, p. 154.

62. Unknown 1817, p. 6.

63. Melton, pp. 31-32, 240; Holm, pp. 34, 69.

64. Melton, pp. 259-260. Daniel Coker (1780-1846), an abolitionist who had been born into slavery in Maryland, also decided to go to Liberia and became an important figure in the church in Sierra Leone.For further discussion see: Gravely 1993, p. 109; Maclin, p. 143.

65. Holm, p. 19.

66. Melton, p. 28; Garrettson himself recounts how he preached to 'five hundred Whites, and almost as many Blacks who stood without.' Simpson, p. 63.

67. Matthews 1963, p. 616.

68. 'Quest. 25. Ought not the assistant to meet the coloured people himself, and appoint as helpers in his absence proper White persons, and not suffer them to stay and meet by themselves? Answ. Yes.' Unknown 1840, vol. 1, p. 12.

69. Richey, pp. 58-59.

70. Richey, p. 54; Simpson, p. 243; Garrettson, pp. 21-22.

71. Garrettson, p. 54; Richey, pp. 58-59.

72. Wesley 1872 , vol.4, p. 184.

73. Person, p. 152.

74. Straker, p. 23; Simpson, p. 268.

75. Coke uses the title 'Mr' for Asbury and brother for a certain (White) Harry Fry. However, he refers to Harry Hosier without any title at all - using the adjectives 'Black' or'poor Harry.' Person, pp. 191, 255.

76. Melton, pp. 49-51.

77. Allen 1833, p. 7; Melton, p. 98.

78. Gravely 1993, p. 110; Allen 1833, p. 12.

79. Allen 1833, p. 13.

80. Allen 1833, pp. 13-15. A similar situation is recounted by Frederick Douglass in his work entitled My Bondage and My Freedom. Douglass 1855, pp. 351-354. 
81. Straker, p. 18.

82. Hempton, pp. 105-106.

83. In 1800 the conference permitted the ordination of some Black preachers as deacons. However, this rule encountered so much opposition that it was never published and only a handful of Blacks were ordained deacons - none were ordained as elders. In 1812, the historian Jesse Lee recounts how the ordination of a man purported to be a slave provoked scandal in the Church. For further discussion see: Melton, p. 30, 44-45; Lee, L., p. 471.

84. Melton, p. 68.

85. Straker p. 21.

86. Melton, p. 240.

87. Gravely 2009, p. 124.

88. Sanneh, p. 190.

89. Macquiban, pp. 3-4. Wesley's father had been jailed on two separate occasions (for debt) and the families' comprehension of the brutal realities of incarceration during this period are graphically illustrated throughout the Wesley brothers' writings. For example: 'In prison within prison staked he lies, And keepers under keepers tyrannize: With weighty fetters gall'd, the sufferers groan, Or closescrew'd rivets crack the solid bone; Their only bed dank earth, unpaved and bare, Their only covering is the chains they wear: Debarr'd from cheerful morn, and human sight, In lonely, restless, and enduring night; The strongest health unsinew'd by disease, And Famine wasting life by slow degrees.'Wesley, S., p. 1.

90. Sanneh, p. 198.

91. Sanneh, p. 190.

92. Walker, p. 80; Melton, p. 224.

93. Walker, p. 1.

94. Gravely 2009, p. 129.

95. Walker, pp. 14-5.

96. Walker, pp. 58, 64-65. For other prominent critics of Colonisation see: Allen 1831, pp. 103-104; Adams, pp. 93-94.

97. Melton, p. 224

98. Melton, pp. 224-225.

99. William Lloyd Garrison (1805-1879), who was particularly inspired by Walker's appeal to the Declaration of Independence, founded the Liberator; which became an important periodical for the abolitionist movement. Garrison highlighting the racist motivation, the 'master sprit' behind the Colonization scheme, declared the United States to be the 'legitimate home' of 'free people of color.' Melton, p. 226; Garrison, pp. 14-15.

100. Bell, p. xi.

101. Melton, p. 226.

102. Melton, pp. 236-238, 245.

103. Melton, pp. 238, 245.

104. Henson had taught himself to become a Methodist preacher when he was a slave. Henson, pp. 13, 26-27; 35-38, 48; Melton, pp. 212-213.

105. Melton, pp. 239-242. 
106. Lowry, p. 6.

107. Douglass 1849, p. 107.

108. Douglass was an active supporter of the suffragist movement, concluding that there was no basis 'in reason or justice' for denying women the vote. Douglas 1881, p. 480.

109. Salley, pp. 60-61; Melton, pp. 204-205.

110. Scott, p. 7.

111. Melton, pp. 227-228.

112. Holm, pp. 41-43.

113. Curtis, p. 115.

114. Elliot, p. 229.

115. The strength of this view is captured in the following citation from Stephen Douglas, who lost to Abraham Lincoln in the 1860 presidential election: 'Abolitionism proposes to destroy the right and extinguish the principle of selfgovernment for which our forefathers waged a seven years' bloody war, and upon which our whole system of free government is founded.' Sheahan, pp. 258-259.

116. He wrote: 'Is the M. E. Church such a "mother of harlots," that to oppose theft [man stealing], robbery and adultery, will endanger her peace and safety? ... No abolitionist wishes the Methodist [Episcopal] Church divided - and if it is not held together by slavery, there is no danger that abolitionism will divide it and if it is held together by the wages of unrighteousness, no matter how soon it is divided - the sooner the better.' Scott, p. 145.

117. Scott, p. 145.

118. Wesley 1872 , vol.5, pp. 294-295.

119. I dedicate this article to Stephen Skuce and Tim Macquiban - agents of God's redemption in my life.

\section{Bibliography}

Adams, Josiah. 1860. Memoir of the Life of John Quincy Adams. Boston: Crosby.

Allen, Richard. 1831. To the Free People of Color [sic] of these United States. The Genius of Universal Emancipation: A Monthly Periodical Work Containing Original Essays, Documents and Facts Relative to the Subject of African Slavery 1(3): 103-104.

Allen, Richard. 1833. The Life Experience and Gospel Labors of the Rt Rev Richard Allen. Philadelphia: Martin \& Boden.

Baker, Frank. 1976. From Wesley to Asbury. Durham, NC: Duke University Press.

Bell, Howard (ed.) 1969. Minutes of the Proceedings of the National Negro Conventions, 1830-1864. New York: Arno Press.

Bibb, Henry. 1849. Narrative of the Life and Adventures of Henry Bibb, An American Slave. New York: H. Bibb.

Brendlinger, Irv. 2006. Social Justice Through the Eyes of Wesley: John Wesley's Theological Challenge to Slavery. Seattle WA: Joshua Press.

Clark, Elmer (ed.) 1958. The Journal and Letters of Francis Asbury in 3 volumes. Nashville, TN: Abingdon.

Clark, James. 1985. English Society 1688-1832. Cambridge: Cambridge University Press. 
Curtis, Lewis (ed.) 1900. The General Conferences of the Methodist Episcopal Church, from 1792 to 1896 . Cincinnati, $\mathrm{OH}$ : Curtis James.

Douglass, Frederick. 1849. Narrative of the Life of Frederick Douglass, an American Slave. Boston, MA: Cornhill.

Douglass, Frederick. 1855. My Bondage and My Freedom. New York: Miller, Orton \& Mulligan.

Douglass, Frederick. 1881. Life and Times of Frederick Douglass. Hartford, CT: Park Publishing.

Elliot, Charles. 1845. History of the Great Secession from the Methodist Episcopal Church. Cincinnati, $\mathrm{OH}$ : Swormstedt.

Emory, Robert. 1856. History of the Discipline of the Methodist Episcopal Church. New York: Carlton \& Porter.

Garrettson, Freeborn. 1820. A Dialogue Between Do-Justice and Professing Christian. Wilmington, DE: Peter Brynberg.

Garrison, William. 1852. Selections from the Writings of William Lloyd Garrison. Boston, MA: R F Wallcut.

Gibson, William. 2001. The Church of England 1688-1832 Unity and Accord. London: Routledge.

Gravely, Will. African Methodisms and the Rise of Black Denominationalism in Richey, Rowe and Schmidt (eds.) 1993. Perspectives on American Methodism: Interpretative Essays. Nashville, TN: Kingswood. pp. 108-126.

Gravely, William. African American Methodism in Abraham, William (ed.) 2009. Oxford Handbook of Methodist Studies. Oxford: Oxford University Press. pp.122-138.

Hempton, David. 2005. Methodism: Empire of the Spirit. New Haven, CT: Yale University Press.

Henson, Josiah. 1849. The Life of Josiah Henson, Formerly a Slave, Now an Inhabitant of Canada. Boston, MA: A. Phelps.

Holm, April. 2017. A Kingdom Divided: Evangelicals, Loyalty and Sectionalism in the Civil War Era. Baton Rouge, LA: Louisiana State University Press.

Jackson, Thomas. 1841. The Life of the Rev. Charles Wesley in 2 volumes. London: John Mason.

Jefferson, Thomas. 1788. Notes on the State of Virginia. Philadelphia, PA: Prichard and Hall. Lawrence, Anna. 'Both Parties Trembled for the Ark of God' Transatlantic Methodism and the American Revolution in Frank, A. and Barbara, S. (eds.) 2008. American Revolution: People and Perspectives. Santa Barbara, CA: ABC Clio. pp.145-168.

Lee, Jesse. 1810. A Short History of the Methodists. Baltimore, MD: Magill and Clime.

Lee, Leroy. 1848. The Life and Times of the Rev. Jesse Lee 1808-1882. Richmond, VA: John Early.

Lowry, Beverly. 2008. Harriet Tubman: Imagining a Life. New York: Anchor Books.

Maclin, H. Daniel Coker in Anderson, G. (ed.) 1999. Biographical Dictionary of Christian Missions. Grand Rapids, MI: Eerdmans. p. 143.

Macquiban, Tim. 2004. Imprisonment and Release in the Writings of the Wesleys Studies in Church History 40:3-4.

Matlack, Lucius. 1849. The History of American Methodism and Slaveholding from 17801849. New York: Spruce Street. 
Matthews, Donald. 1963. The Methodist Mission to the Slaves The Journal of American History 51(54): 615-663.

Matthews, Donald. 1965. Slavery and Methodism: A Chapter in American Morality 17801845. Princeton, NJ: Princeton University Press.

Melton, Gordon. 2007. A Will to Choose: The Origins of African American Methodism. Lanham, MD: Rowman \& Littlefield Publishers.

Person, A. 1815. The Life of the Rev. Thomas Coke, L.L.D. a Clergyman of the Church of England. Leeds: Alexander Cumming.

Pinckney, Charles. 1829. An Address Delivered in Charleston: Before the Agricultural Society of South Carolina, at Its Anniversary Meeting, on Tuesday, the 18th August. Charleston, SC: A.E. Miller.

Price, Richard. 1776. Observations on the Nature of Civil Liberty, the Principles of Government, and the Justice and Policy of the War with America. London: T Cadell.

Raymond, Alan. 1976. 'I Fear God and Honour the King': John Wesley and the American Revolution Church History 45(3):316-328.

Richey, Russell. 1991. Early American Methodism. Bloomington, IN: Indiana University Press.

Salley, Columbus. 1993. The Black 100: a Ranking of the Most Influential AfricanAmericans, Past and Present. Secaucus, NJ: Carol Pub. Group.

Sanneh, Lamin. The World is my Parish: Methodism and the Roots of World Christian Awakening in Abraham, William (ed.) 2009. Oxford Handbook of Methodist Studies. Oxford: Oxford University Press. pp. 188-206.

Scott, Orange. 1838. An Appeal to the Methodist Episcopal Church. Boston, MA: David H Ela.

Sheahan, James. 1860. The Life of Stephen A. Douglas. New York: Harper.

Simpson, Robert (ed.) 1984. American Methodist Pioneer: The Life and Journals of the Rev. Freeborn Garrettson 1752-1827. Rutland, VT: Academy.

Straker, lan. 1998. Black and White and Gray All Over: Freeborn Garrettson and African Methodism Methodist History 37(1):18-27.

Telford, John. 1960. The Letters of the Rev. John Wesley in Eight Volumes. London: Epworth Press.

Thompson, Andrew. 2011. From Societies to Society: The Shift from Holiness to Justice in the Wesleyan Tradition Methodist Review 3:141-172.

Unknown, Author. 1798. The Doctrines and Discipline of the Methodist Episcopal Church. Philadelphia, PA: Henry Tuckniss.

Unknown, Author. 1804. The Doctrines and Discipline of the Methodist Episcopal Church. New York: T Kirk.

Unknown, Author. 1817. A View of Exertions lately made for the Purpose of Colonizing the Free People of Colour in the United States, in Africa or Elsewhere. Washington DC: J Elliot.

Unknown, Author. 1840. Minutes of the Annual Conferences of the Methodist Episcopal Church for the Years 1773-1840. New York: T Mason.

Walker, David. 1830. Appeal, in Four Articles; Together with a Preamble, to the Coloured Citizens of the World, but in Particular, and Very Expressly, to Those of the United States of America. Boston, MA: D Walker. 
Wesley, John. 1782. The Scripture Doctrine Concerning Predestination Election and Reprobation. London: J Paramore.

Wesley, John. 1853. Explanatory Notes Upon the New Testament. New York: Carlton \& Phillips.

Wesley, John. 1872. The Works of John Wesley edited by Thomas Jackson, 3rd edition, 14 volumes. London: Wesleyan Methodist Book Room.

Wesley, Samuel. 1729. The Prison Open'd: A Poem occasioned by the late Glorious Proceedings of the Committee appointed to Enquire into the State of the Gaols of this Kingdom. London.

Wightman, William. 1902. Life of William Capers, One of the Bishops of The Methodist Episcopal Church South. Nashville, TN: Publishing House of the M. E. Church South. 